\title{
Bitkilerin Sıcağa ve Soğuğa Dayanıklılık Bölgelerinin Türkiye Ölçeğinde Coğrafi Bilgi Sistemleri ile Haritalanması
}

\author{
*Meral PEŞKIRCIOĞLU1 $\quad$ Kadir Aytaç ÖZAYDIN¹ $\quad$ Hüseyin ÖZPINAR ${ }^{2}$ \\ Yüksel NADAROĞLU3 ${ }^{3} \quad$ Özden DOKUYUCU ${ }^{3}$ \\ Günseli AYTAÇ CANKURTARAN ${ }^{4} \quad$ Sabahaddin ÜNAL $^{1} \quad$ Osman ŞiMŞEK $^{3}$ \\ ${ }^{1}$ Tarla Bitkileri Merkez Araştırma Enstitüsü, Ankara, \\ ${ }^{2}$ Ege Tarımsal Araştırma Enstitüsü, Izmir \\ ${ }^{3}$ Meteoroloji Genel Müdürlüğü, Ankara \\ ${ }^{4}$ Ulaştırma Denizcilik ve Haberleşme Bakanlığı, Ankara \\ *Correspondence author (Sorumlu yazar) e-mail: mpeskircioglu@tagem.gov.tr
}

Geliş Tarihi (Received): 21.01.2016

Kabul Tarihi (Accepted): 24.05.2016

\section{Öz}

Bitki yetiştiriciliğinde iklimsel faktörler büyük önem arz etmektedir. Bunların başında sıcaklık faktörü gelmektedir. Bu nedenle bu çalışmada sıcaklık parametresi ele alınmış, ülkemizde meyve, sebze, süs bitkileri ve orman ağaçları gibi alanlarda yetiştiricilik yapanların kullanabilecekleri bitkisel üretimde önemli olan sıcaklıkla ilgili alt ve üst sınır değerlerinin dağılımını gösteren haritaların üretilmesi amaçlanmıştır. Gelişmiş ülkelerde bu çalışmalar uzun yıllar önce başlamış ve coğrafi bilgi sistemleri teknikleri de kullanılarak geliştirilmiştir. Bitkiler için çok düşük ve çok yüksek sıcaklıkların dağılımını gösteren haritaların yeni teknolojilerle üretilmesi, ülke kaynaklarının daha verimli bir şekilde kullanılmasını sağlaması açısından önemlidir. Bu çalışmada, 250 iklim istasyonun 1975-2010 yılları arası, düşük ve yüksek sıcaklık parametreleri kullanılarak veri tabanı hazırlanmış, topoğrafya ve yükseltinin de etkisi yansıtılarak Türkiye için 18 sınıfı bitkilerin soğuğa ve 10 sınıflı sıcağa dayanıklılık bölge haritaları üretilmiştir. Böylece yetiştiriciler kendi bölgelerinin riskli sıcaklık aralığını bu haritalardan öğrenerek daha doğru tür ve çeşit seçimi yapabileceklerdir. Bunun sonucunda yurtdışı ile fidan ticareti yapan yerli şirketler ürünlerin zarar görmeyeceği sıcaklık değerine sahip bölge konusunda dünya ülkeleri ile aynı dili konuşabileceklerdir. Aynı zamanda bitki koruma uzmanları da zararlı risk analizi çalışmalarında üretilen bu haritalardan faydalanabileceklerdir.

Anahtar Kelimeler: Bitki sıcağa dayanıklılık bölgeleri, bitki soğuğa dayanıklılık bölgeleri, günlük sıcaklık $30^{\circ} \mathrm{C}$ üzeri gün sayısı, tahmin haritalama, yıllık en düşük sıcaklık

\section{Mapping the Plant Hardiness and Heat Zone at Turkey Scale by Geographic Information System}

\begin{abstract}
Climatic factors are of great importance in plant growth. Temperature is leading fator amng all. This study was aimed to produce maps showing lower and upper temperature limits required for the production of fruit, vegetable, ornomental plants, and forest trees. In developed countries, these studies have started for a long time and the data have been updated using geograpgical information systems techniques. Production of maps for low and high temperature resistance regions of plants by new technologies is important for more productive use of the country resources. In this study, database was prepared by using low and high temperature parameters of 250 climate stations between 1975 and 2010. Eighteen class plant hardiness zone and 10class plant heat zone maps of Turkey were produced reflecting topography and altitude impacts. Thus growers who have trades with abroad will communicate their counterparts more accuretly. People who deals with plant protection will also benefit from the Plant protection people will also benefit from the map to evaluate the pest risk. values were obtained with $6 \mathrm{~kg} \mathrm{~N} / \mathrm{da}$ fertilizing at all yield and quality parameters except semolina yield.
\end{abstract}

Keywords: Number of maximum temperature is more than $30^{\circ} \mathrm{C}$, minimum temperature of a year, plant hardiness zone, plant heat zone, interpolation mapping 


\section{Giriş}

klim; nem, yağış, rüzgâr, güneşlenme gibi parametreleri ile bitki türlerinin dağılım sınırlarını belirleyen önemli faktörlerdendir. İklim parametreleri arasında bitkilerin büyüme ve gelişmeleri için en etkili olan parametre ise sıcaklıktır (Eser 1986; Ağaoğlu ve ark. 1997). Sıcaklık, ekvatordan kutuplara ve deniz seviyesinden dağlara doğru çıkıldıkça azalma gösterir (Güçlü 1994).

Optimum sıcaklık, bitki yaşamı için en uygun sıcaklık olup, her bitkinin yetişebilmesi için belirli ölçüde sıcaklığa intiyaç vardır. Bu nedenle yeryüzünde bitki örtüsü bölgeleri, sıcaklık bölgelerine uyum göstermektedir. Bitkilerin faaliyet gösterdiği alt ve üst sınır değerleri sırası ile 0 ile $5^{\circ} \mathrm{C}$ ve 40 ile $50^{\circ} \mathrm{C}$ ' deki sıcaklıklardır. Bunlardan odunsu yapıdaki bitkiler 20 ile $30^{\circ} \mathrm{C}$ arasındaki sıcaklıktan optimum seviyede yararlanmaktadır (Güçlü 1994). Çünkü bitkilerin optimal sıcaklık sınırı ya da eşiği, bitki tür ve çeşitlerine göre büyük ölçüde farklı olabileceği gibi, bitkilerin içinde bulundukları gelişme devrelerine de büyük ölçüde bağlıdır (Ağaoğlu ve ark. 1997).

Abiyotik fiziksel faktörlerden biri olan sıcaklık, yüksek ya da düşük sıcaklık şeklinde bitkiyi etkilemektedir (Büyük ve ark. 2012). Bitkilerin ortalama veriminin $\% 50$ den fazla azalmasına neden olan abiyotik stres, dünyadaki tarımsal ürün kaybının birincil nedenidir (Bray et al. 2000).

Yüksek sıcaklık stresi, özellikle optimum büyüme sıcaklığındaki $1.5-6.0^{\circ} \mathrm{C}$ lik artış ile fotosentezin engellenmesine, hücre membranının zararına ve hücre ölümüne neden olarak büyüme ve gelişmeyi sınırlandırıcı etki yapmaktadır (Yıldız ve Terzi 2007).

Düşük sıcaklık stresi, bitkilerde hücreleri ve hücreler arası boşlukları dolduran suyun donma noktasına hatta bu sıcaklığa yakın derecelere düştüğünde, ölümle sonuçlanan zararlar şeklinde etkilemektedir (Ağaoğlu 1997). Bu nedenle yetiştiricilik açısından en önemli sorunlardan birisi şüphesiz düşük sıcaklıklardır. Bitkilerin aşırı kış soğuklarında zarar görmeden ilkbahara çıkmaları göründüğü kadar basit bir olay değildir. Bu özellik, bitkilerin genetik yapılarına, beslenme ve uygulanan kültürel işlemlere bağlı olduğu kadar, bitkinin mevsimsel fenolojik gelişme durumuyla da yakından ilgilidir. Diğer taraftan, farklı organların soğuğa dayanıklılık ve hassasiyet durumlarının da birbirinden farklı olması bu konuyu daha da karmaşıklaştırmaktadır (Scebba et al. 1998; Vagujfalvi et al. 1999; Szalai et al. 2001; Yazıcı ve ark. 2001).

Soğuk bölgelerde ağaç ve ağaççıkların yetiştirilmesinde birçok faktör etkili olmaktadır. Bu nedenle soğuk iklim bölgelerinde, park ve bahçe ağaçlarının yetiştirilmesinde, teknik bilgi ve beceriye intiyaç vardır. Arazinin genel topografik yapısı ve karasal iklimin etkisi bitki yetişmesini sınırlayıcı en önemli faktörlerdendir (Güçlü 1994).

Pek çok bitki tür ve çeşidi kendi genetik özellikleri çerçevesinde canlııklarını sürdürebilmek için çoğu kez sınır dereceleriyle karşı karşıya kalabilmektedirler. Dünya üzerinde karasal alanın yaklaşık \%25'lik kısmı $15^{\circ} \mathrm{C}$ 'nin altına düşmeyen ve don zararı açısından güvenilir olan bölgelerden oluşmaktadır. Geri kalan \%75 lik kısımdaki bölgelerde ise belirli dönemlerde sıcaklık $0^{\circ} \mathrm{C}$ 'nin altına düşmesi nedeniyle özellikle hassas bitkiler zarar görebilmektedirler (Aslantaş ve ark. 2010).

Bazı yıllarda meydana gelen şiddetli donlar geçit bölgeleri ile iç bölgelerde ülke tarımını olumsuz yönde etkilemekte ve çeşitli zararlar meydana getirmektedir. Bunlardan özellikle ilkbahar geç donları ve şiddetli kış soğuklarının etkileri tarımın diğer kesimlerinden ziyade meyve yetiştiriciliğinde kendisini fazlasıyle hissettirmektedir. Çünkü çok yıllık meyve ağaçlarının sadece o yılki ürünü zarar görmeyip bir sene sonraki ürünü de zarar görmektedir. Bu durumun önüne geçebilmek için meydana gelen don olaylarının minimum sıcaklıklarını ve bu sıcaklıkta kaldığı süreleri önceden bilmekte yarar vardır (Yazıcı ve ark. 2001).

Bu sektörde meydana gelebilecek maddi zarar boyutlarını tahmin etmek için 2015 yılının inracat verilerine bakmak yeterli olacaktır. 2015 yılı toplam ihracat içinde canlı ağaçlar, diğer bitkiler, kesme çiçekler ve süs bitkilerinin $\% 5$ oranla 77 milyon 429 bin dolar, yenilen meyveler ve sert kabuklu meyvelerin \%3.03 oranla 4 milyar 355 milyon 931 bin dolar pay alması olayın mali boyutunun göz ardı edilemiyeceğini göstermektedir (Anonim 2016).

Meyve ağaçlarının soğuğa dayanıklılıkları türlere göre farklılık göstermektedir. Elma, kiraz, vişne vb. gibi meyve türleri soğuklara daha dayanıklı oldukları halde, kayısı ve badem gibi meyve türleri soğuklardan çok etkilenmektedir. Bu etkide düşük sıcaklığın derecesi, düşme 
hızı, süresi gibi faktörler söz konusu olmaktadır (Küden ve ark. 1998).

Gelişmiş ülkeler arasında bitkilerin dayanabileceği düşük ve yüksek sıcaklık bölgelerinin araştırılması çalışmaları çok uzun yıllar önce Amerika Birleşik Devletleri (ABD)'nin öncülüğünde başlatılmış ve ilerleyen yıllarda bu bilgiler güncellenmiştir (Rehder 1927; Kincer 1928; Wyman and Flint 1985). 1990 yılında ABD Tarım Bakanlığı tarafından ABD, Kanada ve Meksika için istatistik tabanlı bitki soğuğa dayanıkılık haritaları üretilmiştir (Cathey 1990; Cathey and Heriteau 1990; Del Tredici 1990). Sonraki yıllarda Coğrafi Bilgi Sistemleri (CBS) teknolojisi kullanılarak üretilen haritalar kullanıma sunulmuştur (Ellis 2003; Daly et al. 2012). Benzer çalışmalarla Yeni Zelanda, Rusya, Fransa, Avrupa, Kanada, Avusturalya, Çin Halk Cumhuriyeti gibi ülkelerde ve dünyanın bitki soğuğa dayanıklılık bölgeleri haritaları üretilmiştir (Donadieu 1986; DeGaetano and Shulman 1990; Dawson 1991; Widrlechner 1997; McKenney et al. 2001; Magarey et al. 2008).

Bitkiye özgü optimal sıcaklığa sahip alanların belirlenmesi, türlerin ve çeşitlerin daha iyi yetiştirilmesinin sağlanması açısından çok önemlidir. Çünkü her bitki türünün büyüme gösterdiği optimum sıcaklık aralığı bulunduğundan bu aralığın dışında hücresel metabolizma ve dolayısıyle bitki büyümesi olumsuz etkilenmektedir (Burke 1990). Bitkiler için yüksek sıcaklığın olumsuz etkilerine karşı korunmak amacıyle sıcağa dayanıklıık bölge haritası çalışmaları dünyada ilk defa ABD'de Amerikan Bahçe Bitkileri Derneği tarafından 4745 meteoroloji istasyonundan alınan, 19741995 yılları arası yüksek sıcaklık verileri kullanılarak başlatılmıştır (Paulsen 1994; Anonim 1997). Benzer çalışmalar Meksika'nın bitki sıcağa dayanıkılık bölge haritalarının elde edilmesinde uygulanmıştır (Giddings and Esparza 2005). İlgili haritaları üretilmiş olan ülkelerde bölge numarasına göre uygun bitki türleri listeler halinde yayınlanmaktadır (Anonim 2014a, 2014b). Dahası satışa sunulan fide ve fidan belgelerine de o türün uygun olduğu bölge numarası tavsiye amaçlı ilave edilmektedir.

Türkiye'deki üreticiler, gelişmiş ülkelerde uzun zaman önce üretilmiş olan sıcak ve soğuğa dayanıklııı bölge haritalarını gördükten sonra, ürünlerini Türkiye'de satarken, sıcaklık isteklerine göre tavsiye edebilecekleri bölgeyi gösteren bir haritaya intiyaç duymaktadır. Bu intiyaç bugüne kadar kıta ölçeğinde hazırlanan ve yeterince detay içermeyen haritalarla giderilmeye çalışılmıştır. Bu konuda duyulan intiyaç üzerine ilk defa 2009 yılında Meteoroloji Genel Müdürlüğü (MGM) tarafından meteorojik verilere dayanarak, bitki soğuğa dayanıklılık ve bitki sıcağa dayanıklıık bölge haritaları üretilmiştir. Söz konusu haritaları üretmek için Surfer 8.0 yazııımı kullanılmıs ve ilgili sektörün kullanımına açılmıştır.

Türkiye'de daha sonra aynı konuda yapılan benzer bir çalışma ile 2012 yılında 15 orman ağaç türünün dağılımının incelenmesi için bitki soğuk ve sıcağa dayanıklıık bölge haritaları üretilmiştir (Yılmaz and Tolunay 2012). Haritaların elde edilmesinde RST (Regularized Spline with Tension) metodu ile iklim verilerinin kullanıldığı çalışmanın sonucunda Türkiye'de 7 adet soğuğa, 8 adet sıcağa dayanıklı bölge tespit edilmiştir.

Türkiye, gerek bulunduğu coğrafi konum gerekse topoğrafya özellikleri ile son derece farklı iklim koşullarına sahiptir (Atalay 2011). Bu zengin iklim bölgelerinin dağılımı ve özellikleri farklı iklim sınıflandırmalarıyla incelenmiştir. Bunlardan biri olan Köppen-Geiger iklim sınıflandırma sistemine göre Türkiye başlıca Subtropikal, Akdeniz ve Karasal iklim sınıflarının etkisi altındadır (Türkeş 2010). Türkiye, farklı iklim tiplerinin etkisinde olması nedeni ile zengin bitki örtüsüne sahiptir. Bunun en çarpıcı göstergesi 3000'i endemik olan Türkiye'deki bitki türü sayısının toplam 9000 olmasıdır (Uyanık ve ark. 2013; Yücel ve Babuş 2005). İklim sınıflarındaki çeşitlilik, bitki örtüsünü de etkilediği için, yetiştiricilik açısından hangi bitkinin nerede yetişebileceğini bilmek her zaman önemli olmuştur.

Meteorolojik veriler ele alındığında başta sıcaklık olmak üzere yağış, nem gibi meteorolojik değişkenler ile topoğrafya arasında güçlü bir bağlantı olduğundan meteorolojik verilerin çok değişkenli istatistiksel yaklaşımla enterpolasyonunda yardımcı veri olarak yükseklik, eğim ve bakı gibi topoğrafik değişkenlerin kullanılması enterpolasyonun doğruluğunu ve hassasiyetini önemli ölçüde arttırmaktadır (De Pauw 2005). Türkiye'de sıcaklığın dağııımı; enlem, arazinin yönü, eğimi ve yüksekliği, toprak yapısı ile topoğrafik yapının zenginliği ve çeşitliliğinden etkilenmektedir. Dolayısı ile düşük veya yüksek sıcaklık haritaları hazırlanırken topoğrafyanın da etkisinin yansıtılması gerekmektedir. Bu işlemi en iyi gerçekleştirme araçlarından biri de CBS teknolojisidir. Çünkü CBS, konuma dayalı 
veri ve bilgilerin işlenmesi, görsel analitik araçlarla analizlerin yapılması ve kullanıcının bilgiyi etkileşimli kullanmasına olanak sağladığı için problem çözümünde etkin bir sistemdir (Aydınoğlu 2003). Son yıllarda CBS teknolojisindeki gelişmelerle istatistiksel analizlerin de CBS'ye entegrasyonu sağlanmış ve istatistiksel enterpolasyon yöntemleri konumsal veriler için klasik yöntemlere güçlü bir alternatif oluşturmuştur (Öztürk ve Batuk 2010). İklim parametresi haritası elde edilmesinde kullanılan yöntemlerden biri enterpolasyondur. Sonuçta ölçülen değerler yardımı ile tahmin edilen değerlerin kullanılması ile harita elde edilmektedir. Ölçülen ve hesaplanan değerler arasında yüksek korelasyon $(0,92)$ bulunması CBS teknolojisi ile elde edilen haritaların uygunluğunu göstermektedir (Daly et al. 2012).

Tohum ve fidan üreticilerinin ürünlerinin sıcaklık açısından adaptasyon alanlarını belirleyebilecekleri, Türkiye için üretilmiş bitki soğuğa ve sıcağa dayanıklılık bölge haritalarına intiyaç duyulmuştur. Bu çalışma bu intiyaca cevap verebilecek Bitki soğuğa ve sıcağa dayanıkııık bölge haritalarını Türkiye ölçeğinde, CBS teknolojisi kullanarak ve enterpolasyon için yeni geliştirilmiş özel bir program yardımıyla, rakım farkından dolayı meydana gelebilecek sıcaklık değişikliklerinin yansıtıldığı yöntemle bir harita üretmek amaciyle yürütülmüştür.

\section{Materyal ve Metot}

\section{Çalışma Alanı ve Veriler}

Çalışma alanı Akdeniz, Karadeniz, Marmara Denizi ve Ege Denizi ile çevrilidir (Şekil 1). Türkiye $36^{\circ}-42^{\circ}$ kuzey paralelleri ve $26^{\circ}-45^{\circ}$ doğu meridyenleri arasında yer almaktadır. Yüzölçümü 814.578 km²' dir. Ülkenin yarısından fazlası,

1.000 m'yi aşan yüksek alanlardan oluşmaktadır.

\section{İklim Verileri}

Bu çalışmada, Türkiye ölçeğinde gözlem yapılan Meteoroloji Genel Müdürlüğü'ne (MGM) ait 250 adet Büyük Klima İstasyonu'nun 19752010 yılları arasındaki günlük en yüksek ve en düşük hava sıcaklığı değerlerini içeren sayısal veriler kullanılmıştır. Çalışmada bitki soğuğa dayanıklıık haritası için yıllık "en düşük sıcaklık verisi" ve bitki sıcağa dayanıkılık haritası için de "en yüksek sıcaklığı $30^{\circ} \mathrm{C}$ ve üzeri olan gün sayısı" verisi kullanılmıştır. Veri setine Dünya Meteoroloji Örgütü (WMO) iklim kıstaslarına göre en az 30 ve üzeri yıllık verisi olan gözlem istasyonları alınmıştır (Anonim 2001). Veriler daha ileri işlemlere başlamadan önce kontrol edilmiş ve hata giderme işlemleri tamamlanmıştır. Bu amaçla Excel programında yazılan ara yazııımlardan yararlanıımıştır.

\section{Topoğrafik Veri}

CBS analizleri için gerekli girdilerden biri olan Türkiye sayısal yükseklik modelinin (SYM) elde edilmesinde SRTM (Space Radar Topography Mission) verisi kullanılmıştır (Farr et al. 2007). SRTM, Amerika'daki NASA tarafından, $90 \mathrm{~m}$ çözünürlüklü ve yaklaşık $60^{\circ}$ kuzey ve güney enlemleri arasında kalan tüm kara parçalarının sürekli ve yüksek çözünürlüklü sayısal yükseklik modelinin elde edilmesi amacıyle gerçekleştirilmiş bir projedir (Farr and Kobrick 2000).

\section{Coğrafi Veriler}

Türkiye'nin illeri, ilçeleri ve göllerine ait verileri içeren 1: 250000 ölçekli, ESRI shape (.shp) formatındaki vektör verilerdir.

Bitki soğuğa ve sıcaklığa dayanıklılık haritaları için başlıca işlem aşamaları;

1) Veri tabanının hazırlanması,

2) SYM hazırlanması,

3) Veri tabanı ve SYM'nin birlikte enterpolasyon analizinde işlenmesi ile yüzey haritasının üretilmesi ve

4) Yüzey haritasının sınıflandırılması' dır.

Bitki Soğuğa Dayanıkııık Bölge (BSDB) haritasını üretmek için, öncelikle Excel yazılımında $250 \mathrm{iklim}$ istasyonunun enlem, boylam koordinatları ve rakım değerlerinden oluşan temel veri tabanı oluşturularak çalışmalara başlanmıştır. Her bir istasyona ait günlük ölçülen düşük hava sıcaklıklarından, yıllık en düşük hava sıcaklı̆̆ı parametresi belirlenmiştir (Şekil 2). Bunların 1971-2010 yılları arasındaki her yıla ait verileri tek veri tabanında toplanmış, sonra ortalamaları alınarak o istasyona ait uzun yıllar en düşük minimum sıcaklıklar ortalaması hesaplanmıştır. Hesaplamalar sonucunda Excel ortamında veri tabanı oluşturulmuş, sonra CBS ortamında istasyon bazlı koordinatlı verilere bağlı veri tabanı hazırlanmıştır.

Yöntemin diğer girdisi olan topoğrafya verisi için SRTM SYM verisi kullanılmıştır. Bu çalışmada SRTM raster verisinden, Türkiye vektör verisi baz alınarak kesme işlemi 


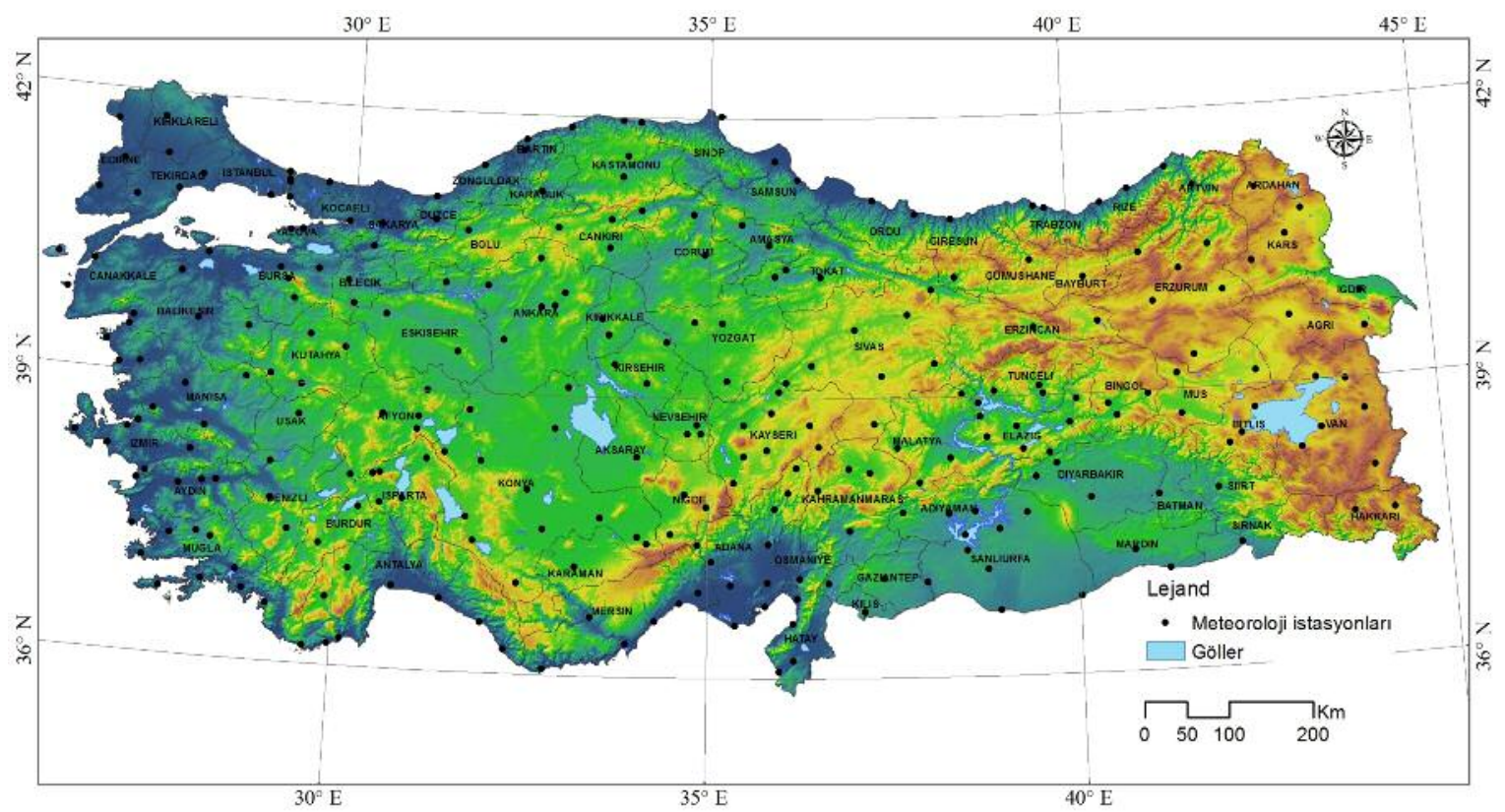

Şekil 1. Çalışma alanı ve meteorolojik istasyonların dağılımı

Figure 1. Study area and distribution of weather stations

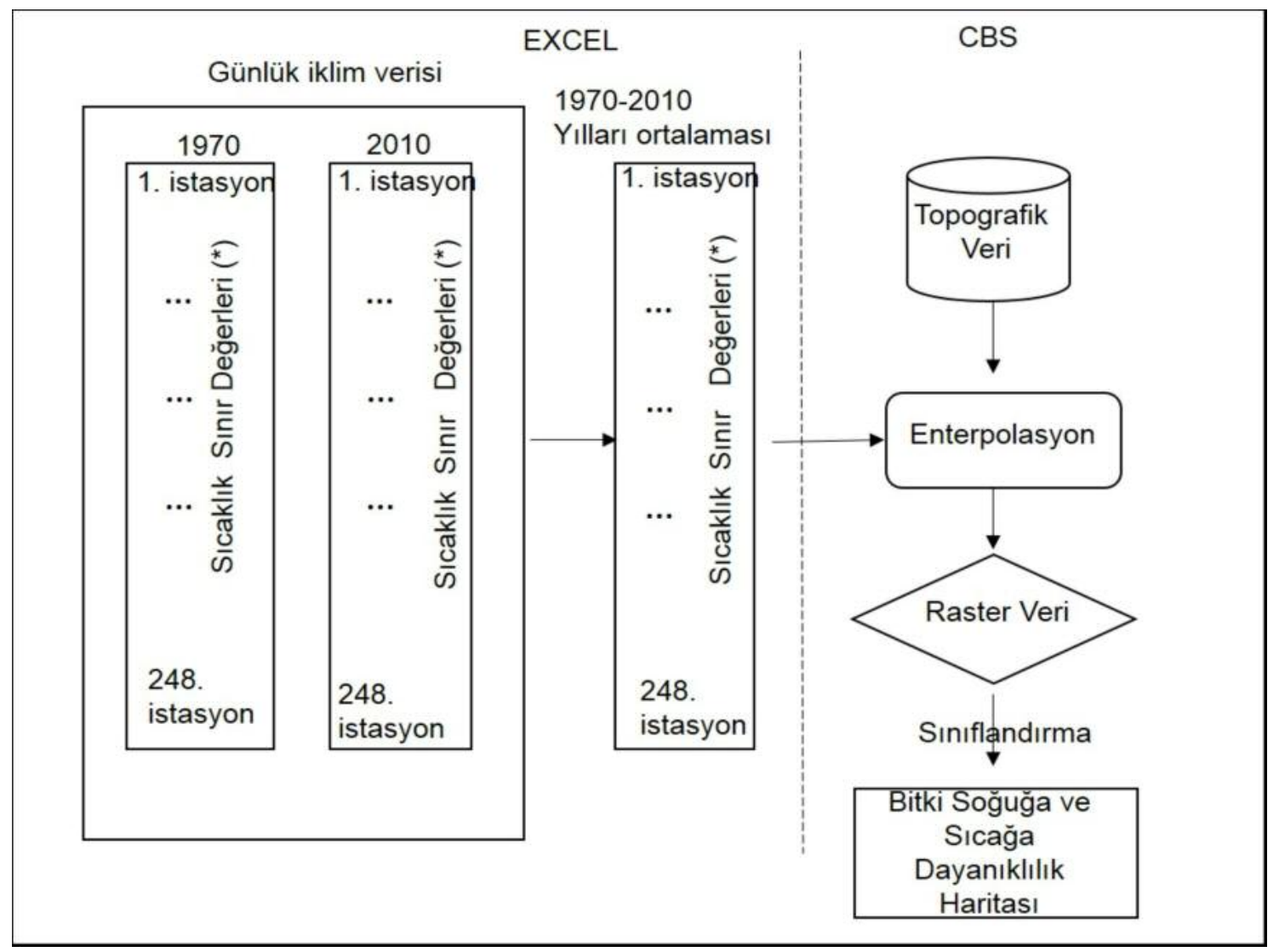

Şekil 2. Yöntem akış şeması (* İklim verisi: Bitki soğuğa dayanıklılık haritası için yılın en düşük sıcaklık derecesi, bitki sıcağa dayanıklılık haritası için günlük en yüksek sıcaklığı $30^{\circ} \mathrm{C}$ üzerindeki gün sayısı alınmıştır.)

Figure 2. Flow chart ( ${ }^{*}$ Climatic data: Extrem minimum temperature of year for plant hardiness zone map and day with number of maximum temperature is more than $30^{\circ} \mathrm{C}$ for plant heat zone map.) 
uygulanmıştır. Elde edilen "Türkiye topoğrafik raster verisinin" teknik hataları giderilerek ASCII formatına çevrilerek enterpolasyon işlemine hazırlanmıştır.

Meteoroloji istasyonlarından ölçülen parametre değerleri noktasal veri olup, bu çalışmada Türkiye ölçeğinde dağılım gösteren alansal meteorolojik veriye intiyaç duyulmuştur. Bunun için CBS tekniklerinin avantajlarından biri olan noktasal veriden alansal veri üretmek amacıyle yapılan analizlerden biri olan enterpolasyon için, ANUSPLINE programı tabanlı, Hutchinson (1995)'un "thin plate smoothing spline" metodu kullanılmıştır. Böylece en düşük sıcaklık dağılımına topoğrafik verinin de işleme dahil edilmesi ile sıcaklık yüzey haritası üretilmiştir.

Sınıflama işlemi için, ArcGIS yazılımının "Spatial Analyst" modülünden yararlanılmıştır (McCoy and Johnston 2001). ABD Tarım Bakanlığı' nın kullandığı sınıflama sistemine göre, BSDB harita skalası $5.6^{\circ} \mathrm{C}$ aralıklarla 13 bölgeden oluşmaktadır. Bölgeler kendi içinde a ve $\mathrm{b}$ şeklinde her biri $2.8^{\circ} \mathrm{C}$ lik iki alt bölgeye ayrılmıştır. 1a bölgesi $-48.3^{\circ} \mathrm{C}$ ile $-51.1^{\circ} \mathrm{C}$ arasında en düşük sıcaklık kuşağını temsil ederken, $13 \mathrm{~b}$ bölgesi $18.3^{\circ} \mathrm{C}$ ile $21.1^{\circ} \mathrm{C}$ arası sıcaklık değerlerini temsil etmektedir (Anonim 2012; Daly et al. 2012).

Bitki sıcağa dayanıklılı bölge haritasının üretilmesinde BSDB haritasının üretilmesi için kullanılan yöntem aynen uygulanmıştır. Farklı olarak veri tabanı için günlük en yüksek sıcaklığı $30^{\circ} \mathrm{C}$ üzeri olan gün sayısı parametresi kullanılmıştır (Şekil 2). Sınıflama işlemi için ABD Tarım Bakanlığının standartları esas alınmış ve bu sisteme göre sınıf aralıkları 1, 7, 14, 30, 45, $60,90,120,150,180$ gün olarak belirlenmiștir. Her iki harita önce float (.flt) formatında elde edilmiş, daha sonra grid formatına çevrilmiştir.

\section{İstatistik Analizler}

Ölçülen değerlerle, hesaplanan değerler arasındaki ilişki korelasyon analizi ile incelenmiştir. Bu amaçla SPSS yazılımı kullanılarak verilerin dağıım grafiği çıkarılmış, değerler $t$-testi ile kıyaslanmıştır. Bu çalışmanın yanında BSDB haritasının üretilmesi için kullanılan meteorolojik veriler ile rakım arasındaki ilişki korelasyon analizleri ile ortaya konmuştur (Kalaycı 2009).

\section{Bulgular ve Tartışma}

CBS teknikleri kullanılarak meteorolojik verilerin topoğrafik verilerle işleme konularak enterpolasyon işlemi sonucunda Bitki Soğuğa
Dayanıkııık Bölge Haritası (BSDB) üretilmiştir (Şekil 3). Elde edilen sonuç haritası ABD Tarım Bakanlığının belirlediği ve bütün ülkelerde de uygulanan standartlardaki sınıflara ayrılmış ve Türkiye için 2a ile 10b sınıfları arasında yer alan 18 bölge tespit edilmiştir.

BSDB haritası, Türkiye'de geçişli bölgeler şeklinde ortaya çıkmıştır (Şekil 3). Buna karşın başta $A B D$ ve diğer ülkelerin çoğuna ait BSDB haritalarında bölgeler enine kuşaklar şeklinde veya birbirine komşu olan bölgeler şeklindedir (Anonim 2012). Buradaki karmaşık durumun nedeni, Türkiye'de bu yapının birçok faktörün etkisi altında ortaya çıkmış olmasıdır. Türkiye' nin iklim koşulları başlıca dünya genelinde hüküm süren atmosfer dolaşımı ile fiziki coğrafya özelliklerinin etkisi altındadır. Sadece coğrafi konumu dikkate alındığında bile güneyinden kuzeyine doğru sıcaklığın giderek azaldığı, kışın az olan güneşlenme süresinin yazın arttığı, özellikle doğrudan gelen güneş radyasyonunu kuzeye bakan eğimli yamaçlarda az aldığı, buna karşın güneye bakan yamaçlarına çok fazla düştüğü ortaya çıkar. Bu durum Türkiye'nin sıcaklık, yağış gibi iklim koşullarında ve bitki örtüsünün yayılışında önemli farklııkların ortaya çıkmasına yol açmaktadır. Benzer şekilde yükselti, dağların uzanış doğrultuları ve baktığı yön, denizsel etkiler ve karasallık durumuna bağlı çeşitlilik iklim tiplerinin zenginliğini arttıran faktörler olarak değerlendirilmektedir (Atalay 2011).

BSDB haritasında bazı illerin bölge numaraları Adana: 9b, Ankara: 7b, Antalya: 10a, İstanbul: 9a, Konya: 7a olarak belirlenmiștir. Buna ilave olarak örneğin Ankara il merkezi 7b no' lu bölgede görünürken, Ankara il sınırları içinde $8 a, 7 a, 6 a, 6 b, 5 a$ ve $5 b$ bölgelerinin de aynı zamanda dağııım gösterdiği açıkça görülmektedir (Şekil 4). Bunun nedeni haritanın çözünürlüğünün $90 \mathrm{~m}$ olduğu için ince detayları içermesi ve sonuçta bir il hatta ilçe sınırları içinde birden fazla sayıda BSD bölgesinin yer almasıdır. Yetiştiriciler açısından ilgili alanın hangi bölgeye dahil olduğuna ait en güvenilir bilgi, sayısal haritanın kullanılması ile mümkün olabilecektir.

Elde edilen harita istatistiksel yöntemler ile hesaplanan tahmini bir harita olup doğruluğunun test edilmesi gerekir (Daly et al. 2012). Bu amaçla yapılan analizde, uzun yıllar ortalaması en düşük sıcaklık değeri ile enterpolasyonla hesaplanan değer arasında önemli bir korelasyon $(r=0.99)$ elde edilmiştir. Bu sonuç dağılım diyagramında noktaların aynı doğru üzerindeki konumundan da açıkça görülmektedir 
Çizelge 1. Bitki soğuğa dayanıklılık bölgelerinin alansal dağılımı

Table 1. Spatial distribution of plant hardiness zones

\begin{tabular}{|c|c|c|}
\hline Bölge Kod no & $\begin{array}{l}\text { Bölge Alanı } \\
\left(\mathrm{km}^{2}\right)\end{array}$ & $\begin{array}{c}\text { Toplam alan } \\
\text { içindeki payı (\%) }\end{array}$ \\
\hline $2 a$ & 8.62 & 0.0011 \\
\hline $2 b$ & 19.39 & 0.0025 \\
\hline $3 a$ & 104.89 & 0.01 \\
\hline $3 b$ & 1248.20 & 0.16 \\
\hline $4 a$ & 7532.09 & 0.96 \\
\hline $4 b$ & 36629.46 & 4.67 \\
\hline $5 a$ & 47202.42 & 6.02 \\
\hline $5 b$ & 61059.76 & 7.79 \\
\hline $6 a$ & 62004.27 & 7.91 \\
\hline $6 b$ & 85779.86 & 10.95 \\
\hline $7 a$ & 128899.76 & 16.45 \\
\hline $7 \mathrm{~b}$ & 89328.87 & 11.40 \\
\hline $8 a$ & 91880.40 & 11.73 \\
\hline $8 b$ & 76810.31 & 9.80 \\
\hline $9 a$ & 59613.94 & 7.61 \\
\hline $9 b$ & 25761.33 & 3.29 \\
\hline $10 a$ & 9581.60 & 1.22 \\
\hline $10 \mathrm{~b}$ & 96.84 & 0.01 \\
\hline Toplam & $783.562,00$ & 100.00 \\
\hline
\end{tabular}

Bölge Kodu Zone cod, Bölge alanı Coverage area,

Toplam alan içindeki payı Percent area

(Şekil 5). Yapılan $t$ testi ölçülen ve hesaplanan değerlerin ortalamaları arasında önemli bir fark olmadığını ( $p=0.63$ ) ortaya çıkarmıştır (Kalaycı 2009). Bu sonuç meteroloji istasyonu olmayan bütün alanlardaki haritadan hesaplanan değerlerin, ölçülen değerleri doğru temsil ettiğini göstermesi bakımından önemlidir.

18 bölgenin alansal dağılımı incelendiğinde; en geniş alan 7a bölgesinde yer almakta, onu $8 a$ ve $7 \mathrm{~b}$ bölgeleri takip etmektedir (Çizelge 1). En büyük alana sahip bu üç bölgenin dağılım gösterdiği iller incelenmiş̧tir.

7a bölgesi (-17.8 ile $\left.-15^{\circ} \mathrm{C}\right)$ en çok Kırıkkale, Ankara, Eskişehir illerinde olmak üzere Kuzeydoğu Anadolu'dan başlayan kıyıya paralel sıradağlar boyunca devam edip, İç Batı Anadolu geçit bölgesinden, Anadolu'nun güney kıyılarına oradan da baraj ve akarsu alanlarını çevreleyip Güneydoğu'da Diyarbakır, Siirt, Şırnak, Hakkari'deki dağların yüksek kesimlerinde son bulmaktadır.

8a bölgesi, en çok Trakya ve Güneydoğu Anadolu'da büyük alanlar halinde yer almış ilave olarak Anadolu yarımadasının kuzey-batı ve güney bölgeleri boyunca $7 a$ bölgesinin hemen dışında ince bir sıra halinde dağılım göstermiştir.

7b bölgesi de 7a bölgesinin sınırları boyunca Anadolu'nun iç kesimine doğru yer almış ve Kırıkkale, Ankara, Eskişehir, Göller yöresi ve Diyarbakır ile baraj ve akarsuların çevresinde dağılım göstermiştir. En az alana sahip bölge olarak 10b bölgesi görünmektedir.
Türkiye geneli incelendiğinde diğer bölgelere göre daha yüksek sıcaklık derecesine sahip 8a $9 \mathrm{~b}$ arası bölgeler, Anadolu yarımadasının denizlerle çevrili üç tarafındaki kıyılar ve Güneydoğu Anadolu'da ülke sınırı boyunca dağılım göstermiştir. Diğer yandan KöppenGeiger'in iklim sınıflandırmasına göre Marmara, Ege, Akdeniz ve Güneydoğu Anadolu bölgeleri ile İç Anadolu'nun batı ve güney bölümlerinin "Akdeniz iklim sınıfı"na girmesi bu sonuçlarla paralellik göstermektedir (Türkeş 2010).

BSDB haritasında $6 b-7 b$ arası bölgeler ağırlıklı olarak Orta Anadolu'da dağılım göstermiştir. Köppen- Geiger iklim sınıflandırmasına göre Türkiye'de İç Anadolu Bölgesi'nin orta bölümü ve Doğu Anadolu'nun doğusunda Van-lğdır bölümü "subtropikal step iklim sınıfı"nın özelliklerini taşımaktadır (Türkeş 2010).

2a ile $5 a$ bölgesi arası en düşük sıcaklıkların olduğu bölgeler, ağırlıklı olarak Orta Anadolu'nun doğusunda ve Doğu Anadolu Bölgesinde, yüksek dağlık alanların olduğu bölgelerde dağılım göstermiştir. Atalay (2011), sıcaklıkların en fazla düştüğü yerlerin Doğu Anadolu'nun yüksek platoları ve buralardaki çukur alanlar olduğunu, kışın karla kaplı ve havanın sakin olduğu günlerde gece sırasında soğuyarak ağırlaşan havanın çukur kesimlere yığılmasıyla sıcaklığın çok düştüğünü belirtmektedir. Diğer bir yaklaşım olan Köppen-Geiger iklim sınıflandırmasına göre; İç ve Doğu Anadolu Bölgelerinin genel olarak Orta-Kuzey bölümlerinde uzanan geniş bir bölge yazı kurak nemli karasal (soğuk), olarak tanımlanmıştır. Kuzeydoğu Anadolu'nun (Erzurum - Kars bölümü), ve İç Anadolu'nun Kuzeyindeki dar bir alan ise kurak mevsimi olmayan nemli karasal (soğuk) iklim sınıfında yer almaktadır (Türkeş 2010).

BSDB haritasında bölgelerin dağılımı genel olarak incelendiğinde Anadolu yarımadasının doğusuna gidildikçe yükseltinin arttığı sıcaklıkların da düştüğü görülmektedir. Yükseltinin artması ile sıcaklığın düşmesinin istatistiki açıdan ne derece ilişkili olduğunu araştırmak için en düşük sıcaklık değerleri ile rakım değerleri arasında "korelasyon analizi" yapılmıştır (Kalaycı 2009)

$\mathrm{Bu}$ analiz sonucunda rakım ile en düşük sıcaklık arasında kuvvetli negatif yönlü $(r=-0.881)$ bir ilişki bulunmuştur. Buradan rakımın yükseldikçe en düşük sıcaklık derecesinin giderek düştüğü sonucuna varılmıştır. Ayrıca en düşük sıcaklık derecesindeki değişmelerin 


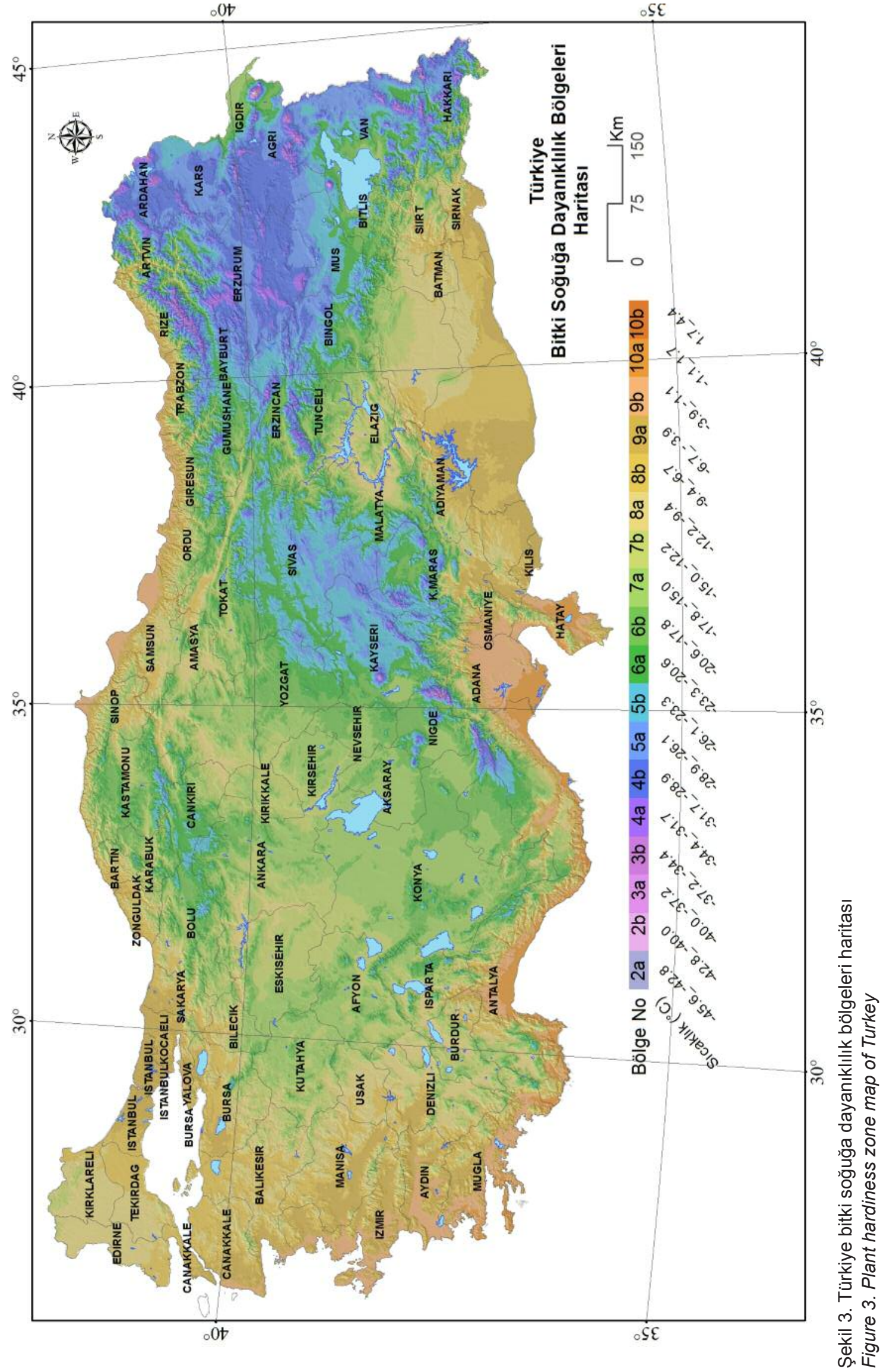




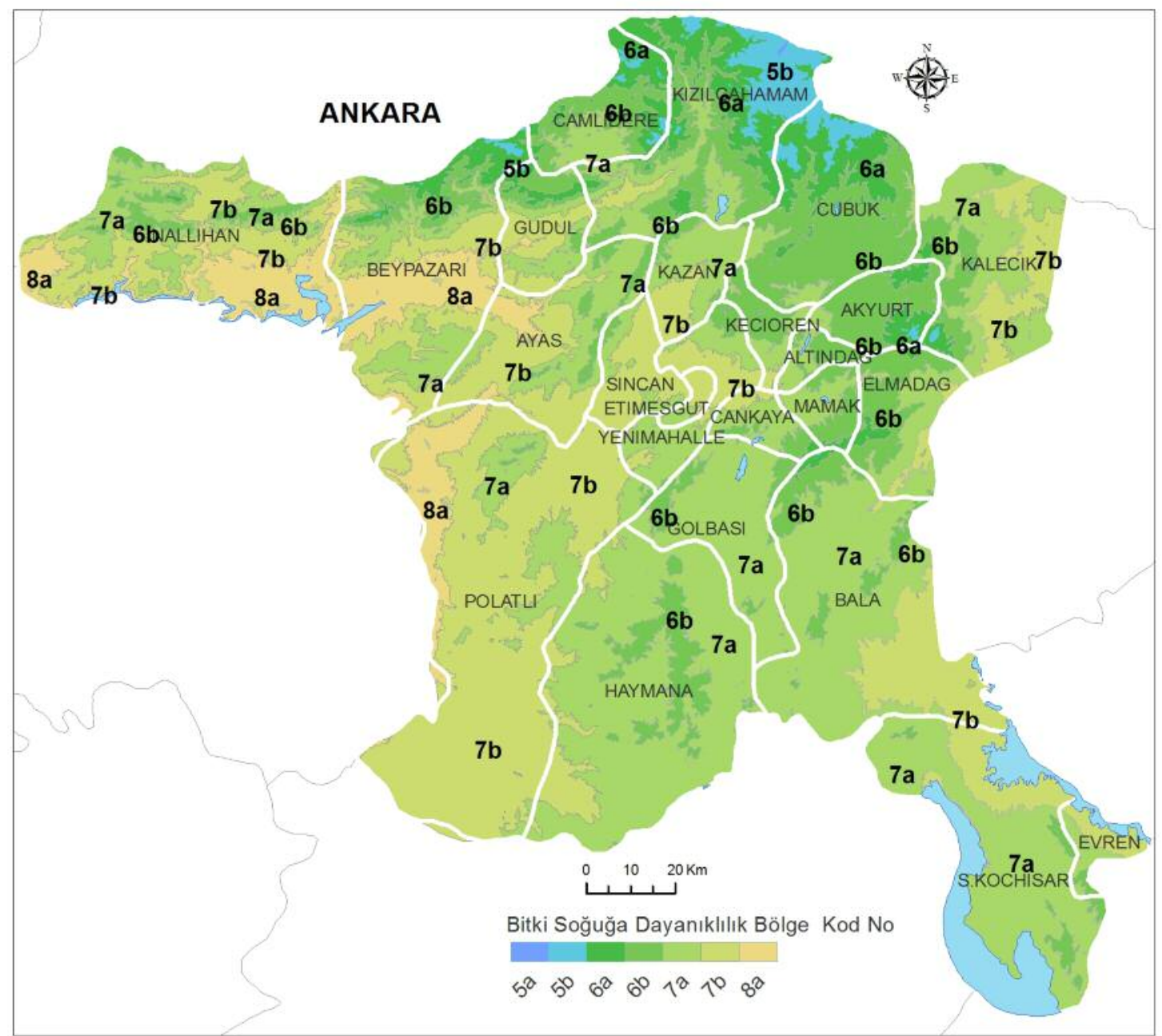

Şekil 4. Ankara ilinin bitki soğuğa dayanıklılık bölgelerinin ilçelere göre dağılımı Figure 4. Distribution of plant hardiness zones of based on the districts in Ankara

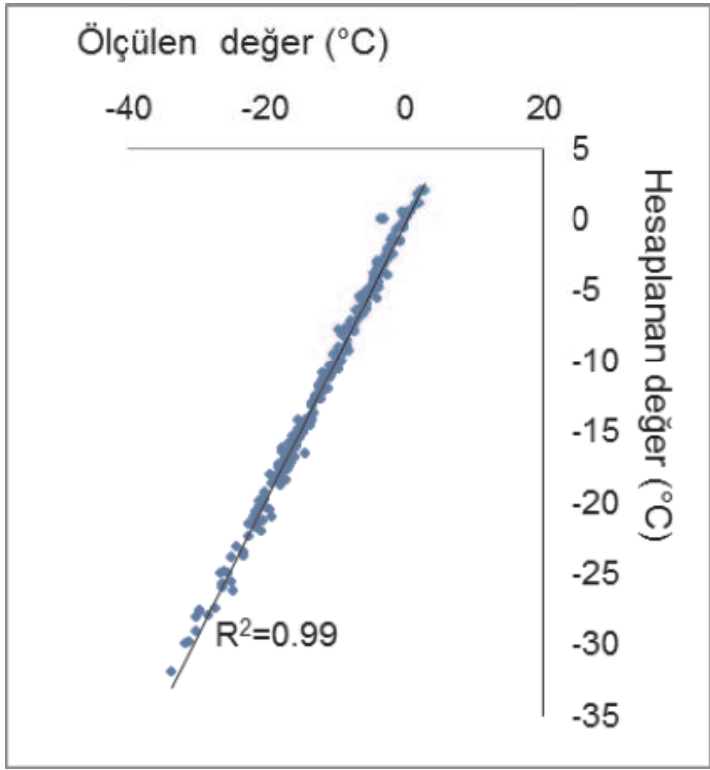

Şekil 5. Ölçülen değerler ve hesaplanan değerler arasındaki korelasyon grafiği(BSDB haritası için)

Figure 5. Scatter plot between measured and estimated data (for PHZ map) $\left(r^{2}=0.776\right) \% 77.6$ ' sı rakım tarafından açıklandığı sonucuna varılmıştır (Şekil 6). Bu negatif ilişkiye örnek olarak kıyı kesimlerde 12 ile $6^{\circ} \mathrm{C}$ arasında seyreden Ocak ayı sıcaklığının, İç Anadolu'da 1 ile $-3^{\circ} \mathrm{C}^{\prime}$ ye düşerken Doğu Anadolu'da $-10^{\circ} \mathrm{C}$ ' nin altına kadar düşmesi verilebilir (Atalay 2011). Bunun nedeni arazinin deniz seviyesinden olan yüksekliği arttıkça sıcaklık derecesinde devamlı azalma görülmesi ve bu azalmanın dağlık bölgelerde her $1000 \mathrm{~m}$ yükseklikte $10^{\circ} \mathrm{C}$ olarak kabul edilmesidir (Cox and Atkins 1979).

Düşük sıcaklıkların görüldüğü yerler kadar, bu sıcaklıkların kışın bölgelere ve aylara göre dağılımı da önemlidir (Daly et al. 2012). Bu amaçla "en düşük sıcaklıkların aylara göre dağılımını" gösteren harita üretilmiştir (Şekil 7). Bu haritada en düşük sıcaklıkların Aralık, Ocak, Şubat ve Mart aylarındaki mekânsal dağılımı ortaya konmuştur. Aralık ayında; Anadolu'nun iç kısımlarındaki geçit bölgelerinde ve Doğu Anadolu bölgesinde kara ikliminin hakim olduğu 


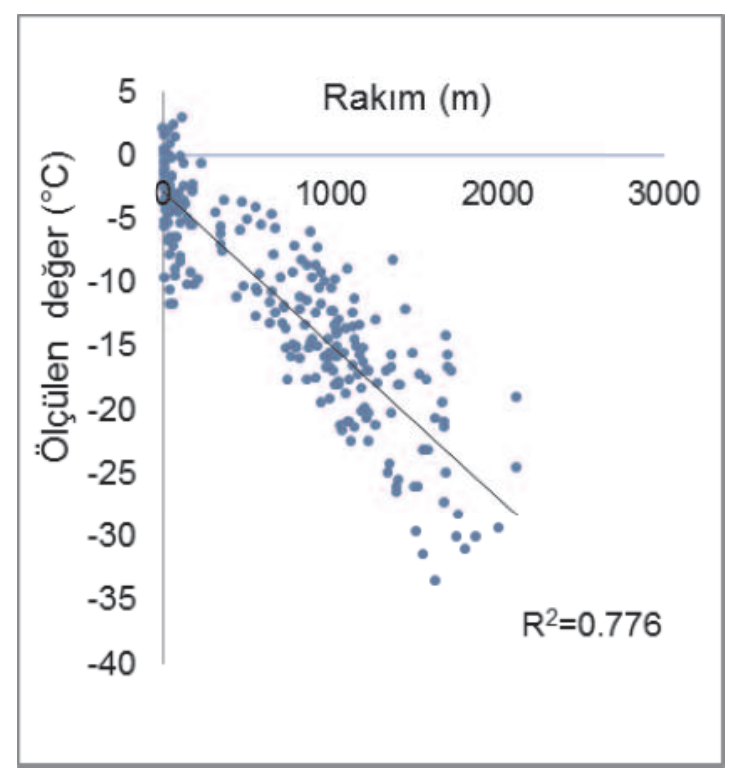

Şekil 6. En düşük sıcaklık ile rakım arasındaki korelasyona ait saçılım grafiği (BSDB haritası için))

Figure 6. Scatter plot between extreme minimum temperatures and altitudes (for PHZ map)

alanlarda görülmektedir. Bu durum yükselti yanında arazilerin kar örtüsüyle kaplı olmasının da bir sonucudur (Atalay 2011).

Ocak ayında, Anadolu yarımadasının Karadeniz, Ege, Marmara ve Akdeniz kıyıları boyunca Akdeniz ikliminin görüldüğü alanlarda ve Güneydoğu Anadolu'daki baraj çevresindeki alanlarda tespit edilmiştir. Coğrafi enlem ve yükseltiye bağlı olarak, aynı enlemdeki kıyı bölgelerde karaya göre denizsel etki altında olması nedeni ile kışlar daha ılımandır. (Atalay 2011).

Şubat ayında; en düşük sıcaklıklar Anadolu'nun Batı Güney sınırları boyunca
İstanbul, Balıkesir, İzmir, Aydın, Muğla, Antalya, Mersin, Adana, Gaziantep, Mardin'de gözlenmiştir. Anadolu'da don olaylı günlerin sona ermesi kıyı kuşağında başlayarak İç Anadolu'dan Doğu Anadolu'nun yüksek kesimlerine doğru kaymaktadır (Atalay 2011).

Mart ayında ise sadece Bursa, Antalya, Adana ve Hatay olmak üzere çok az birkaç noktada kaydedilmiştir. Bu veriler don olaylı günleri takip etmek açısından önemlidir.

Meteoroloji istasyonu bazında ölçülen gerçek değerlere dayanan bu harita, yetiştiriciler için kışın bitkiler açısından hayati önemi olan düşük sıcaklıkların zararından korunmak amacıyla Türkiye genelinde aylık dağılımı hakkında fikir sahibi olunması adına önemlidir. Çünkü güneş enerjisi ile ortaya çıkan sıcaklığın derecesi; zamana, enleme, arazinin yönü ve eğimine, yüksekliğine, havanın bulutlu ya da açık oluşuna, toprak rengine, yapısına ve bitki örtüsüne göre değişiklik göstermektedir (Eser 1986).

Bitki sıcağa dayanıklılık bölge haritası 10 sınıflı olarak grid formatında elde edilmiştir (Şekil 8). Haritadaki bazı il merkezlerinin konumları incelendiğinde Adana: 9, Ankara: 5, Trabzon: 3 no'lu bölgelerde olduğu tespit edilmiştir. Bölgelerin dağılımını daha yakından incelemek için illerden örnek olarak Ankara haritası incelenmiştir. Ankara il merkezinin 5 no'lu bölgeye dahil olmasına karşın, il sınırları içinde 7, 6, 4, 3, 2, 1 no'lu bölgelerin de dağılım gösterdiği görülmüştür (Şekil 9). Bunun nedeni Türkiye'de enlem, arazinin yönü, yüksekliği, toprak yapısı gibi faktörler çok çeşitli olması nedeni ile bölgelerin dağılımı küçük alanlarda bile değişkenlik göstermesidir (Aydınoğlu 2003).

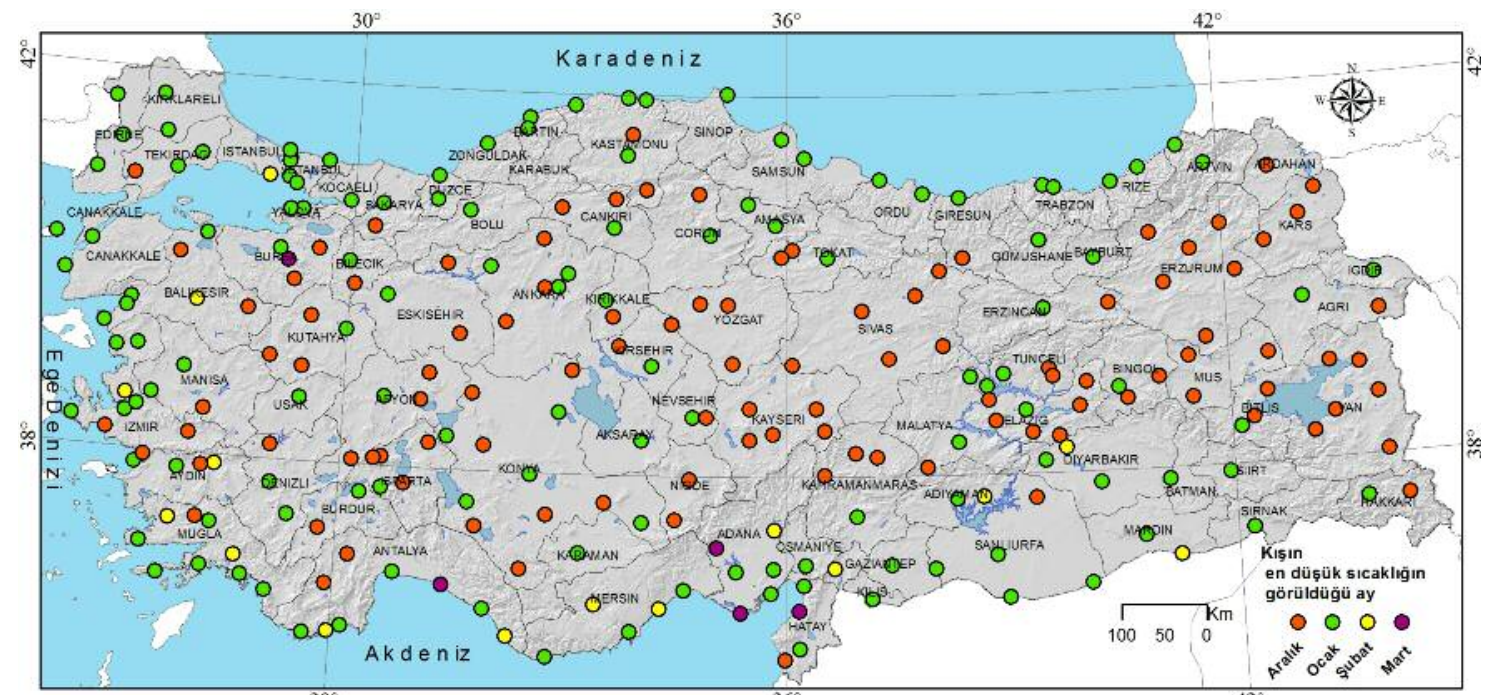

Şekil 7. Yıl içindeki en düşük sıcaklığın kış aylarına görê dağııımı

Figure 7. Distribution of extreme minimum temperature of year according to winter months 


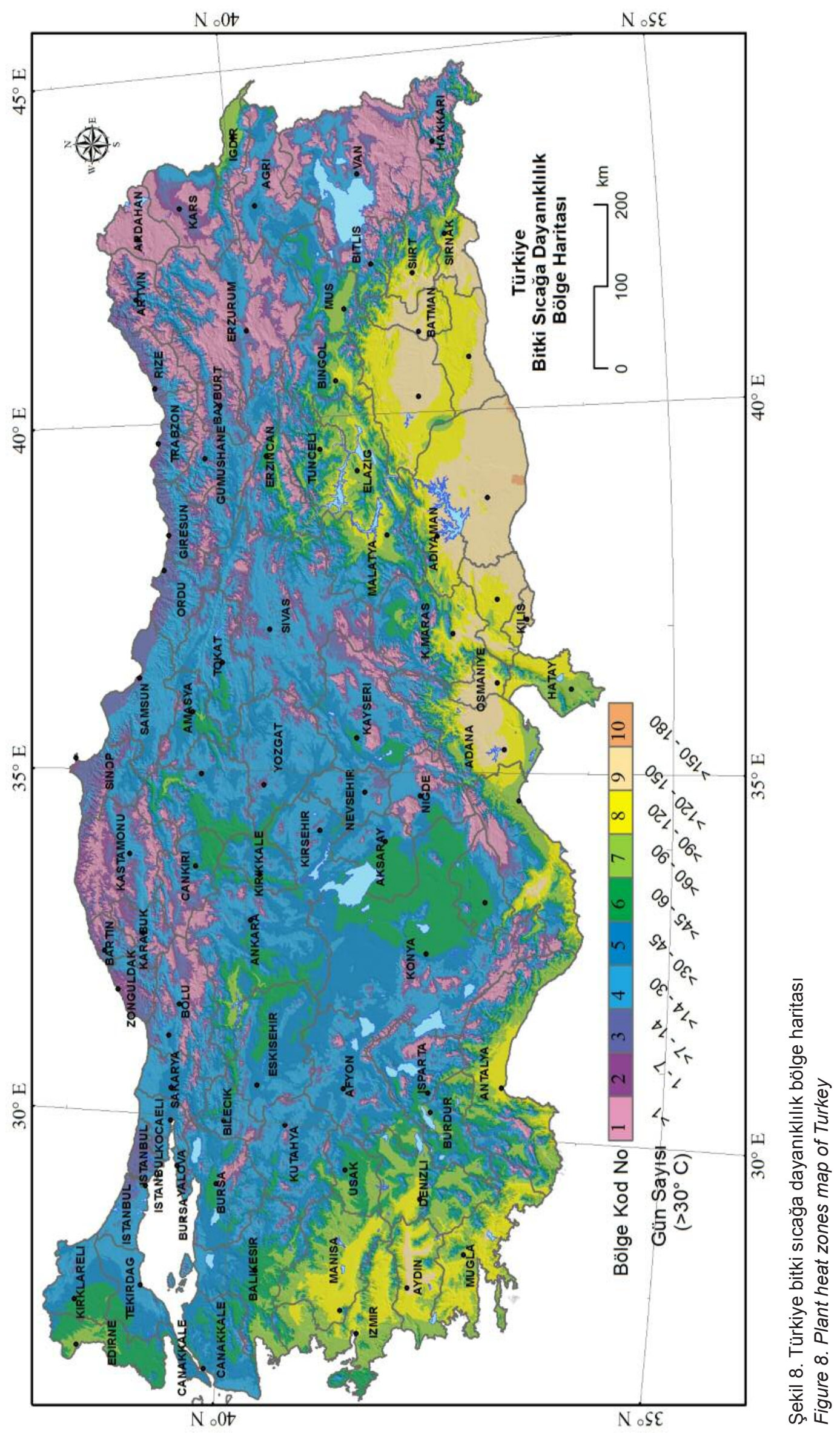




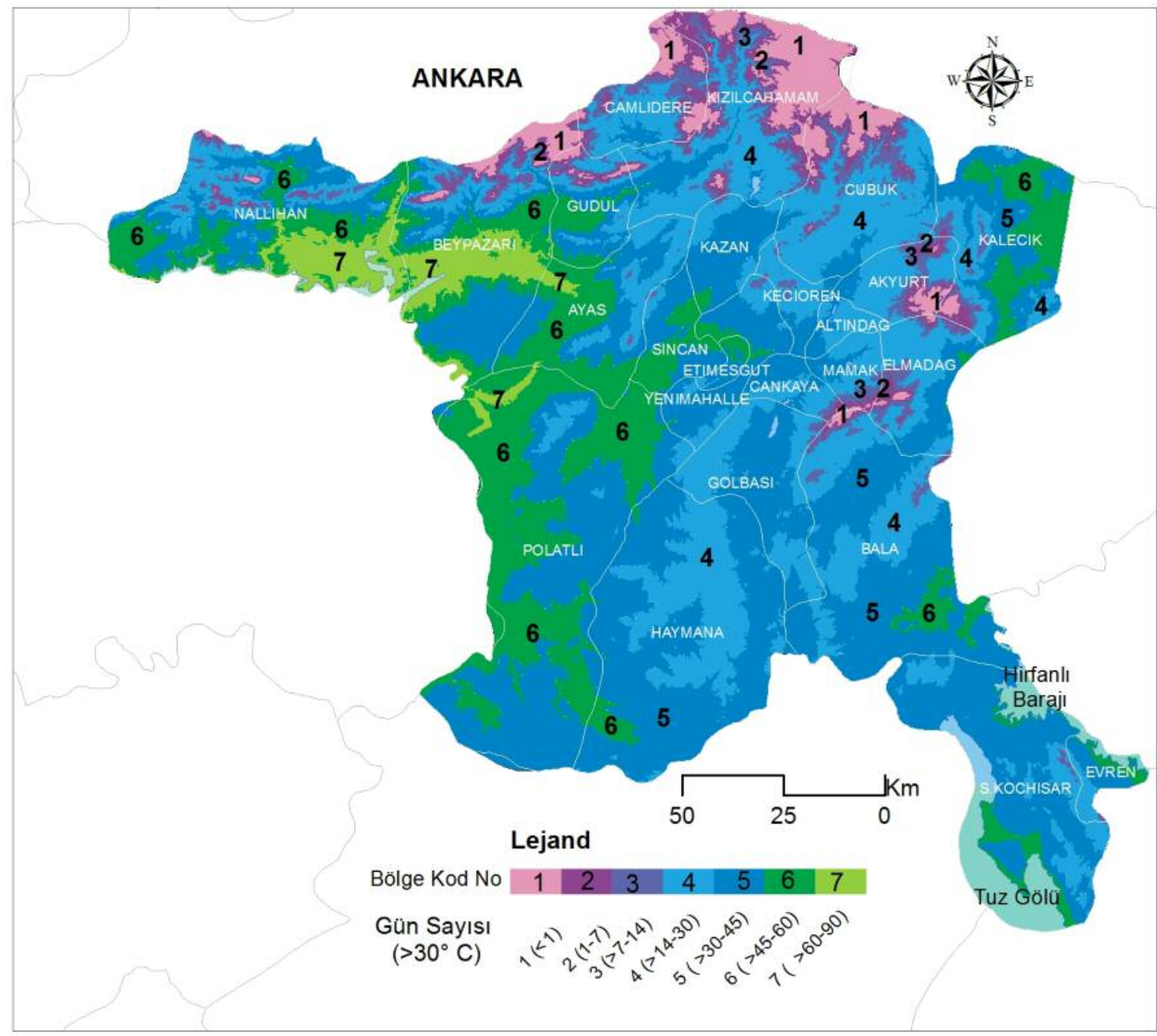

Şekil 9. Ankara ilinin bitki sıcağa dayanıklılık bölgeleri

Figure 9. Plant heat zones of Ankara Province

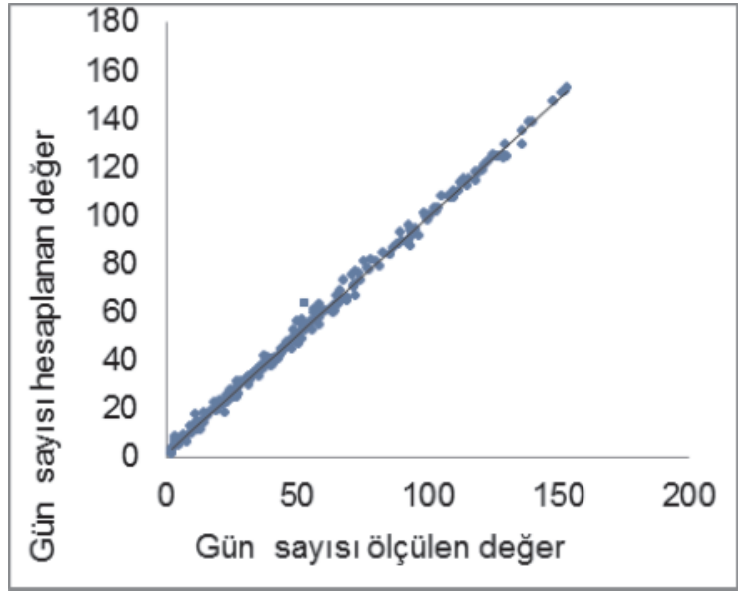

Şekil 10. Bitki sıcağa dayanıkılık bölge haritası için ölçülen değerlerle hesaplanan değerler arasındaki korelasyon saçılım grafiği

Figure 10. Scatter plot between measured values and estimated values (for plant heat zone map)
Bitki sıcağa dayanıklılık haritası için de ölçülen ve hesaplanan değerler arasındaki iliş̧i incelenmiş ve iki değeri arasında pozitif ve güçlü bir ilişki ( $r=0.97)$ tespit edilmiştir (Şekil 10). Ayrıca enterpolasyonla hesaplanan değerler ile ölçülen değerler arasındaki farklılı̆ıı önemsiz $(p=0.247)$ olduğu bulunmuştur (Kalaycı 2009). Tespit edilen 10 bölgenin alansal dağılımı incelendiğinde en büyük alana sahip bölgelerin sırasıyle 4,5 ve 6 no'lu bölgeler olduğu görülmüştür (Çizelge 2). En küçük alan ise 10 no'lu bölge olarak belirlenmiştir.

En yüksek değerleri içeren 8-9-10 no'lu bölgeler haritada (sarı, krem ve turuncu renklerde) bariz olarak Ege Bölgesi ve Güneydoğu Anadolu Bölgesinde dağılım göstermiştir. Ege bölgesinde tipik Akdeniz ikliminin yazları sıcak ve kurak geçen etkisinin yanısıra, rakım ve enlem etkisi açıkça görülmektedir (Atalay 2011). 9 ve 10 no'lu bölgelerin en çok dağılım gösterdiği diğer bir 
Çizelge 2. Bitki sıcağa dayanıklılık bölgelerinin alansal dağılımı

Table 2. Spatial distribution of plant heat zones

\begin{tabular}{crr}
\hline $\begin{array}{c}\text { Bölge } \\
\text { Kodu }\end{array}$ & Bölge alanı $\left(\mathrm{km}^{2}\right)$ & $\begin{array}{r}\text { Toplam alan } \\
\text { içindeki payı }(\%)\end{array}$ \\
\hline 1 & 81412.09 & 10.39 \\
2 & 37767.69 & 4.82 \\
3 & 67778.11 & 8.65 \\
4 & 182961.73 & 23.35 \\
5 & 139395.68 & 17.79 \\
6 & 90031.27 & 11.49 \\
7 & 73263.05 & 9.35 \\
8 & 65270.71 & 8.33 \\
9 & 45368.24 & 5.79 \\
10 & 313.42 & 0.04 \\
\hline Toplam & 783562.00 & 100.00 \\
\hline
\end{tabular}

Bölge Kodu Zone cod, Bölge alanı Coverage area,

Toplam alan içindeki payı Percent area

bölge olan Güneydoğu Anadolu Bölgesi' nde görülen aşırı sıcaklık artışı ise bağıl nemin düşük olmasıyla yüzeye gelen doğrudan radyasyonun zemine çarptıktan sonra sezilebilir sıcaklık halinde havaya dahil olmasıyla ilgilidir (Atalay 2011).

Anadolu'nun çevresini saran yüksek dağlar boyunca ve Doğu Anadolu'nun yüksek dağlık kısımlarında 1 ve 2 no' lu bölgeler (açık ve koyu mor renklerde) dağılım göstermiştir.

En düşük değerlerin çıktığı bölgeler yüksek sıradağların en yüksek noktalarının bulunduğu alanlar olarak belirlenmiştir. Anadolu'nun kuzey kısmının düşük enlemlerde olması, yüksek sıradağların rakım etkisi, Karadeniz Bölgesindeki yıllık yağış miktarı yüksek olan kesimlerde sürekli bulutlu havanın bulunması nedenleri ile bu alanlarda $30^{\circ} \mathrm{C}$ üzerindeki sıcaklık gösteren gün sayısı bakımından oldukça düşük olan bölgeler dağılım göstermiştir (Atalay 2011).

Söz konusu bitki türü için düşük ve yüksek sıcaklık eşiklerine göre zarar görmeyeceği bölgelerin tavsiye edilmesinde, bu çalışma ile üretilen haritalardaki bölge numaraları, tohum, fide ve fidan ticaretinde ortak dili konuşmayı sağlaması açısından büyük kolaylık sağlayacaktır. Sektörde sadece ihracat kısmında 25 bin kişi istihdam edilmekte olup, dolaylı istihdam ise yaklaşık 300.000 kişidir. Sektör ülkedeki sosyal yapıya yeni iş alanlarının yaratılması ve istihdam edilen kesimlere barınma ve eğitim imkanları sağlanması ile katkı sağlamaktadır. Sektörün ihracatdaki payı da göz önünde bulundurulursa üretilen bu haritaların önemi daha iyi anlaşılmaktadır.

\section{Sonuç}

Bu çalışma ile, uluslararası standartlara uygun Bitki Soğuklara Dayanıklılık ve Bitki Sıcağa Dayanıklılık bölge haritaları Türkiye ölçeğinde elde edilmiştir. Illk harita 18 sınıflı, ikincisi de 10 sınıflıdır.

Böylece bahçe bitkileri, meyve ağaçları, orman ağaçları, süs bitkileri yetiştiricileri, bitki bilimcileri ve araştırmacıların adaptasyon çalışmaları yanısıra bitki korumacıların hastalık ve zararlıların risk analizinde kullanabileceği önemli bir veri üretilmiştir.

Bundan sonraki çalışmalarda ülkemizde yetişen bitkilerin, çeşit bazında dayanabileceği en düşük ve en yüksek sıcaklık aralıkları belirlenmelidir. Buna ilave olarak her bir bölgedeki sıcaklık aralıklarında zarar görmeyecek bitkilerin listelerinin hazırlanması gerekmektedir.

\section{Kaynaklar}

Ağaoğlu S., Çelik H., Çelik M., Fidan Y., Gülşen Y., Günay A., Halloran N., Köksal I. ve Yanmaz R., 1997. Genel Bahçe Bitkileri, A.Ü. Ziraat Fakültesi Eğitim, Araştırma ve Geliştirme Vakfı Yayınları No:4. Ankara

Anonim, 1997. ASHS, Plant Heat-Zone Map. American Society for Horticulture Science. Virginia,USA (http://www.ahs.org/gardeningresources/gardening-maps/heat-zone-map) (Erişim tarihi: 1.12.2015)

Anonim, 2001. Guide to climatological practices (No:100). World Meteorological Organization (WMO), Geneva, Switzerland

Anonim, 2012. USDA Plant Hardiness Zone Map. Agricultural Research Service. US Department of Agriculture 3 (http://planthardiness.ars.usda.gov/PHZMWe b/Default.aspx) (Erişim tarihi: 15.11.2012)

Anonim, 2014a. The Garden.org Plants Database/ Details.http://www.garden.org/plantfinder/inde x.php?keyword=\&sort=botanical\&type=AN\&h ardiness $=07 \&$ moisture $=\&$ light $=$ \&heightRange $=\&$ shape $=\&$ soil_condition $=\& q=$ search\&searc h. $x=64 \&$ search.y=3 (Erişim tarihi: 01.10.2014

Anonim, 2014b. The United States National Arboretum. Indicator plant examples. Listed by zone.http://www.usna.usda.gov/Hardzone /hrdzo 4.html (Erişim tarihi:1.10.2014)

Anonim, 2016. TUIK. 2015-2016 İstatistik Tablolar. Yıllara göre dış ticaret. Fasıllara göre İhracat. http://www.tuik.gov.tr/PreTablo.do?alt_id=104 6. (Erişim tarihi. 03.03.2016) 
Aslantaş R., Karakurt H., Karakurt Y., 2010. Bitkilerin Düşük Sıcaklıklara Dayanımında Hücresel ve Moleküler Mekanizmalar. Journal of Agricultural Faculty of Atatürk University, 41(2): 157-167

Aydınoğlu A. Ç., 2003. İnternet Tabanlı CBS Uygulaması: Trabzon İli Örneği. Türk Mühendis ve Mimar Odaları Birliği Harita ve Kadastro Mühendisleri Odası, 9:305-314

Atalay İ., 2011.Türkiye'nin İklim Koşulları. Türkiye İklim Atlası. İnkilap Yayınları, s. 9-54

Bray E. A., Bailey-Serres J., and Weretilnyk E. , 2000. Responses to abiotic stresses. In: Buchanan B, Gruissem W, Jones R (Eds), Biochemistry and molecular biology of plants, pp. 11581203

Burke J. J., 1990. High Temperature Stress and Adaptaiton in Crops, In: Alscher, RG, Cummings JR (Eds), Stress Response in Plants: Adaptation and Acclimation Mechanisms, pp. 295-309, Wileyliss, New York

Büyük İ., Soydam-Aydın S. ve Aras S., 2012. Bitkilerin Stres Koşullarına verdiği Moleküler Cevaplar. Türk Hijyen ve Deneysel Biyoloji Dergisi, 69 (2): 97-110

Cathey H.M., 1990. USDA Plant Hardiness Zone Map. USDA Misc. Publ. 1475. (http://www.usna.usda.gov/Hardzone/hzmne1.html) (Erişim tarihi: 15.11.2015)

Cathey H.M. and Heriteau J. ,1990 . Mapping it out. Amer. Nurseryman, 171(5):55-59 and 1-63

Cox G.W. and Atkins M.D., 1979. Agricultural Ecology. Printed in the United States of America, pp. 721

Daly C., Widrlechner M.P., Halbleib M.D., Smith J.I. and Gibson W.P., 2012. Development of New USDA Plant Hardiness Zone Map fort he United States. Journal of Applied Meteorology and Climatology, Volume 51:242-264

DeGaetano A.T. and Shulman M.D., 1990. A climatic classification of plant hardiness in the United States and Canada .Agric. For. Meteor., $51: 333-351$

De Pauw E., 2005. "Monitoring Agricultural Drought in the Near East", in: V.K. Boken, A.P. Cracnell and R.L. HEATHCOTE (eds.), Monitoring and Predicting Agricultural Drought: A Global Study, Oxford University Press, New York, Chepter 16, pp. 208-224

Dawson I., 1991. Plant Hardiness Zones for Australia. Aust. Hort., 90(8):37-39

Del Tredici P., 1990. The new USDA plant hardiness zone map. Arnoldia, Vol.50, No:3, pp. 16-20
Donadieu P., 1986. Geographical determination of the cold hardiness of plants. P.H.M.- Revue Horticole. No: 272, pp. 13-17

Ellis D., 2003. The USDA Plant hardiness zone map, 2003 edition. Amer. Gard. 82(3):30-35

Eser D., 1986. Tarımsal Ekoloji. A. Ü. Ziraat Fakültesi Yayınları: 975, Ders Kitabı:287, Ankara

Farr T.G. and Kobrick M., 2000. Shuttle radar topography mission produces a wealth of data, Eos Trans. AGU, 81(48):583-585

Farr T.G., Rosen P.A., Caro E., Crippen R., Duren R., Hensley S., Kobrick M., Paller M., Rodriguez E. And Roth L., 2007. The Shuttle Radar Topography Mission, Rev Geophys., 45, RG2004, doi: 10.1029/2005RG000183. An edited version of this paper was published by AGU. Copyright 2007 American Geophysical Union

Giddings E.L. and Esparza S.M., 2005. Plant Heat Zones of Mexico. Revista Chapingo Serie Horticulture 11(2):365-369

Güçlü K., 1994. Soğuk İklim Bölgelerinde Ağaç Yetiştiriciliği. Journal of the Faculty of Agriculture, 25(1):118-126

Hutchinson M.F., 1995. Interpolating mean rainfall using thin plate smoothing splines. International Journal of Geographic Information Systems 9: 385-403

Kalaycı Ş., 2009. SPSS Uygulamalı Çok Değişkenli İstatistik Teknikleri. Asil Yayın Dağıtım, Ankara, pp. 74-79 and 115-120

Kincer J.B., 1928. Atlas of American AgricultureClimate: Temperature, Sunshine and Wind U.S. Goverment Printing Office, pp. 34

Küden Ayzın, Küden Ali, Paydaş S, Kaşka N, ve Imrak B., 1998. Bazı iklim Meyve Tür ve Ceşitlerinin Soğuğa Dayanıklılığı Üzerinde Çalışmalar. Tr. J. of Agriculture and Forestry. 22, pp. 101-109

Magarey R.D., Borchert D.M., Schegel J.W. Sentelhas P.C. and Reichardt K., 2008. Global plant hardiness zones for phytosanitary risk analysis. Universidade de Sao Paulo, Escola Superior de Agricultura "Luiz de Queiroz" (ESALQ), Piracicaba, Brazil, Scientia Agricola, 2008, 65, Special, pp. 54-59

McCoy J.and Johnston K., 2001. Environmental systems research institute. Using ArcGIS spatial analyst: GIS by ESRI. Environmental Systems Research Institute

McKenney D.W., Hutchinson F.M., Kesteven L.J., and Venier L.A., 2001. Canada's plant hardiness zones revisited sing modern climate interpolation techniques. Can. J. Plant Sci. $81: 129-143$ 
Öztürk D. ve Batuk F., 2010. Meteorolojik verilerin CBS ve Çok Değişkenli İstatistiksel Analiz Yöntemleriyle Konumsal Enterpolasyonu. Uluslararası Katılımlı "Meteoroloji Sempozyumu, Devlet Meteoroloji Genel Müdürlüğü, Ankara, s. 27-28

Uyanık M., Kara M.Ş., Gürbüz B. ve Özgen Y., 2013. Türkiye'de Bitki Çeşitliliği ve Endemizm. Ekoloji 2013 Sempozyumu, Tekirdağ. 02-04

Paulsen G.M., 1994. High temperature response of crop plants. Physiology and determination of crop yield (physiologyandde), pp. 365-389

Rehder A., 1927. Manual of cultivated trees and Shurbs. Macmillan, pp. 209

Scebba F., Sebastiani L., and Vitagliano C., 1998. Changes in activity of antioxidative enzymes in wheat (Triticum aestivum) seedlings under cold acclimation. Physiologia Plantarum, 104(4):747-752

Szalai G., Jvea T., Paldi E.and Dubacq J.P., 2001. Changes in the fatty acid unsaturation after hardening in wheat chrosome substitution lines with different cold tolerance. J. Plant Physiol., 158: 663-666

Türkeş M., 2010. 29. Bölüm İklimlerin Sınıflandırılması. Klimatoloji ve Meteroloji. Kriter Yayın, 63:559-574, İstanbul
Vagujfalvi A., Kerepesi I., Galiba G., Tischner T. and Sutka J., 1999. Frost hardiness depending on carbohydrate changes during cold acclimation in wheat. Plant Sci., 144:85-92

Widrlechner M. P., 1997. Hardiness zones in China Color map. USDA-ARS North Central Regional Plant Introduction Station, Ames, lowa

Wyman D. and Flint H.L., 1985. Plant Hardinesszone maps. Arnoldia, 45(4): 32-34

Yazıcı K., Dal B. ve Baktır İ., 2001. Meyve Yetiştiriciliğinde Don ve Soğuk Zararının Etki Mekanizmaları. Derim, 18(4):169-179

Yıldız M. ve Terzi H., 2007. Bitkilerin Yüksek Sıcaklık Stresine Toleransının Hücre Canlılığı ve Fotosentetik Pigmentasyon Testleri ile Belirlenmesi. Erciyes Üniversitesi Fen Bilimleri Enstitüsü Dergisi 23 (1-2): 47-60

Yılmaz O. Y. and Tolunay D., 2012. Distribution of the major forest tree species in Turkey within spatially interpolated plant heat and hardiness zone maps. Forest - Biogeosciences and Forestry (2012) 5:83-92

Yücel M. ve Babuş D., 2005. Doğa Korumanın Tarihçesi ve Türkiye'deki Gelişmeler. Doğu Akdeniz Ormancılık Araştırma Müdürlüğü DOA Dergisi (Journal of DOA), Sayı:11, s.151-175 